\title{
Trust, Confidence and Social capital in the democratization process of Eastern
} Countries

\author{
Vincenzo Memoli \\ Vincenzo Memoli is an MA student in Political Science and International Relations at \\ the University of Molise, Italy
}

\begin{abstract}
Current theories on the Eastern European Countries support the idea that the governments produce democracy (Choen, 1997, Levi, 1998, 1999; Offe, 1999, Rothnstein, 2001). While some authors show a failure to find correlation between aggregate measures of social capital and democratization level (Dowley, Silver, 2001), others give evidence that distrust for politician or parties is a peculiarity of many eastern countries (Schmitter, 1994).

Using the European and World Values Studies (1995-1997) and considering six Eastern countries (Bulgaria, Estonia, Latvia, Lithuania, Poland and Slovenia), we analyzed, with a model of structural equation, the impact of social trust, social capital, democracy support, and other socio-demographic variables on the level of democratization (Free House, 1997).

The results, on the aggregate level, show that:

i) trust can produce democracy support (Inglehart, 1999) and democracy (Uslaner, 2002) but not the contrary as Levi and other scholars claim;

ii) social capital, although registered at low levels, has an acceptable relationship both to democracy support and to democratic level;

iii) the scarce democracy support (confidence in public institutions) has a negative impact on the democratic level.
\end{abstract}

The new democracy and democratization Since the fall of the Berlin Wall, many non-democratic regimes have undergone a transition to democracy, that in the East Europe we can image as a "domino effect" or, talking about out the metaphor, "effect of diffusion" (Starr, 1991).

The nature of this process is surely ambivalent if we consider two aspects: on one hand, the political trust is determined by specific transitional processes and conditions in each particular country; on the other hand, taking into account the fast information exchange, we cannot ignore the influence of socio-political changes in Western countries on the Eastern states, defined as new democracies because they don't have democratic traditions.

In this sense, we need to include the possibility that certain disillusionment with representative democracy, which can be seen in Western countries, may also create more scepticism and criticism in postCommunist countries with respect to democracy and its institutions.

The metaphor of the domino effect is well fitting if we think that from August to December 1989, six countries changed regime: the breakdown of non-democratic communist regimes, which started in Poland (August 1989) and continued in the other countries, has inspired many authors to invoke the "diffusion effect" in their research (Huntington, 1990; Lipset, 1994; Linz Stepan, 1996).

The literature on democratic transitions has focused on political processes and choice of actor to explain regime changes, thereby failing to investigate whether structural factors affect the recent rise of transitions to democracy (Rustow, 1970; O'Donnel, Schmitter, 1986; Di Palma, 1990; Przeworski, 1991; Mainwairing et 
al. 1992). And it has synthesized the collapse of state socialism largely as a reaction to the interaction of two specific factors: economic decline and the international consequences of the Gorbachev reforms (Bunce, 1984).

Many studies of the new democracies that have emerged over the past two decade have emphasized the importance of a strong and active civil society to the consolidation of democracy. Especially with regard to the post-communist countries, scholars and democratic activists, alike, have lamented the absence or obliteration of traditions of independent civic engagement and a widespread tendency toward passive reliance on the state. In this sense, the advanced Western democracies, and above all the United States, have typically been taken as models to be emulated (Lundestad, 1998).

An explanation for the situation typical of the post-communist countries is offered from the dictatorship theory of missing social capital. In fact, many authors agree that dictatorships destroy social capital (Raiser, 1999; Paldam, Svedsen, 2000). The effects are considered to be even stronger when comparing a developed country to a transition country because in the developed country we see an interaction between different individuals from different groups. Looking at the history, we can say that many of these countries have had the possibility to establish a civic society for centuries, while the transition countries come from a completely different historical and institutional background.

In this study we focus attention on six Eastern countries surveyed in the World Values Study (1995-1997), specifically: Bulgaria, Estonia, Latvia, Lithuania, Poland and Slovenia.

Using the cultural approach, we can move from the idea that confidence in institutions, which is an indirect indicator of democracy support, is important for democracy, and that democracy requires a civic culture in which citizens manifest such basic values as trust. The assumption is that societies with low levels of trust are poorly suited to the establishment of democratic institutions (Putnam, 1993).

Many scholars have postulated that rising living standards and increasing levels of education facilitate democratization (Lipset, 1960; Lipset and Scheneider, 1983; Linz, 1988; Weatherford, 1989).

Yet, others assert that democratic traditions can be created in societies with a high degree of mutual trust and interest in politics (Almond and Verba, 1963; Easton, 1965, 1975; Wildavsky, 1987; Eckestein, 1988; Inglehart, 1990), where there is participation in voluntary organizations (Putnam, 1993).

This paper first verifies, empirically, whether the stock of social capital and confidence in institutions are different for each country. And then this is followed by a model of structural equation to understand how social capital, confidence in institutions, and some socio-demographic variables explain the democratic level of the countries (rating - democracy index classified by the Freedom House, 1997).

The principal results show that:

- trust, confuting the Levi idea, constructs democracy and not vice versa;

- social capital contributes both to the confidence in public institutions and to the democratization process, although the effect is weak;

- confidence in institutions has an inverse relationship with democratic level, evidencing the slowness with which the democratization process proceeds.

Social Capital and Democracy

One concept that has received much attention among social scientists is "social capital," particularly among students of countries undergoing democratization.

Social capital is a concept with high explicative power: a reliable and valid tool through which we can see and explain the 
reality that envelops the people. Nevertheless, few scholars emphasise those aspects. Just as rare are empirical studies on this specific aspect, although social capital is seen as the cement of society, to paraphrase an interesting book by John Elster (1999).

Many kinds of social capital are currently recognized (Serageldin, 1996) and many definitions have been given.

On a macro level it is possible to divide the concept of social capital into two trends. The first one is based on a structural dimension. It refers to the fundamental elements of the network such as types of ties and connections and the social organization of the community (Bourdieu, 1983; Coleman, 1988; Fountain, 1998). The second one is based on a dimension in which social capital resides and includes the social norms, trust, shared understanding and those elements that hold people together (Jacobs, 1961; Putnam, 1993, 2000; Fukuyama, 1999; Cohen \& Prusak, 2001).

Particularly interesting is the intersection of the theoretical positions by Putnam, who says social capital "refers to features of social organization such as trust, norms and networks, that can improve the efficiency of society by facilitating coordinated action" (Putnam 1993:167).

The concept, as many authors claimed, is attractive theoretically, as it places so much emphasis on the activities of ordinary citizens, after a decade of bringing the state back into the centre of comparative political analysis.

Also Diamond (1997) has articulated in several writings that social capital is best developed in the organisations of civil society that are largely non-political and certainly non-partisan. In other words, voluntary organizations, especially multiple and cross-cutting group affiliations, are seen to be vital to the development of democracy (Kornhauser 1960, Lipset 1960). This idea also underlies earlier discussions of political cleavage and political culture (Almond and Verba 1963). Yet, "the proliferation of autonomous associations and steady increases in the cognitive mobilization of the mass have seriously undetermined the foundations of authoritarian rule" (Shin, 1994:152). In recent years, the interest of scholars in the connections between associations and democracy has increased (Fung, 2003). The emergent idea is that attendance of associations creates opportunities for citizens and groups to participate directly in governance.

These are associations that enrol a wide range of people of different social backgrounds and interests. The participation in associations, then, appears to be fundamental and essential to build social capital (Putnam, 1993:173). In a similar way, "virtues and viability of a democracy depend on the robustness of its associational life" (Warren, 2001: 3).

But, participation in associations is not the only indicator of social capital. In fact, there are a number of facets of social capital and these are themselves interdependent.

Another relevant concept is trust which is held to be an "essential component of social capital" because it facilitates the cooperation necessary for coordination within society (Putnam, 1993, p. 170).

Raiser (1999) argues that "extended trust" is fundamental in the transition countries in order to permit the evolution of the economic system, and we add, of the democracy.

Putnam's social capital thesis has been subjected to any number of scholarly responses, retorts, and replications (Tarrow, 1997), but the fact remains that this theoretical position is lauded by most, although if it's compared with the other forms of capital (financial, human), social capital is less tangible, and hence more difficult to measure.

In this analysis we consider trust and associational life as indicators of social capital. 


\section{Measures of social capital}

Social capital, in its complexity and indeterminateness, brings to the mind more a nebula than a clean horizon. Setting aside the metaphor, it's clear that it is necessary to deepen the concept in order to operationalize it. To do this, we can use the data from the World Values Study for the year 1995 .

The first concept considered is the trust because it plays a central role in modern society and its politics. As Simmel (1950: 326), echoed by other authors (Arrow, 1972:357; Ostrom, 1990; Putnam 1993, 1995, 2000; Fukuyama 1995; Warren 1999) says, 'trust is one of the most important synthetic forces within society'.

In the countries considered on average $21,6 \%$ of the respondents trust other people.

High levels of trust are registered in Bulgaria, where the percentage of people that "trust in the others" is $29,5 \%$, while the lowest level of trust appears in Slovenia where $14,5 \%$ trust others.

Tab. 1 Trust in the other (\% values)

\begin{tabular}{|c|c|c|c|}
\hline & Careful & Trusted & Total $(N)$ \\
\hline Bulgaria & 70,5 & 29,5 & $100,0(888)$ \\
\hline Estonia & 78,5 & 21,5 & $100,0(999)$ \\
\hline Latvia & 77,8 & 22,2 & $100,0(1.160)$ \\
\hline Lithuania & 78,1 & 21,9 & $100,0(981)$ \\
\hline Poland & 82,1 & 17,9 & $100,0(1.089)$ \\
\hline Slovenia & 84,5 & 14,5 & $100,0(991)$ \\
\hline
\end{tabular}

Source: Our analysis on the dataset of ICPR 2790

The low level of "trust in others" confirms the problems of democracies in transition (Bielasiak 2002; Morlino 1998) and demonstrates the long road that eastern countries must tread to reach a satisfying level of democratization. (How do these averages compare to Western European states? Are they really different?)

Besides, considering that the trust is based on the similarity of currently salient values (Earle, Cvetkovick, 1995) we can say that the level of trust measured across nations, when considered with the legacy of Communism, shows a large effect on cul- ture, in terms of distrust respect of the past. We cannot deepen this aspect in the absence of indicators, but we cannot exclude it in terms of effect. In fact, as Inglehart (1997) says, trust is a key component of pro-democratic attitudes that lay the foundation for popular constitutions. In other words, it is impossible have trust whereas the concept of democracy was unfamiliar.

As Toqueville (1968) said, the associative network of a country constitutes a specific element to create good social capital: in associations the citizens learn how to stay together, to participate in group experiences and, above all, to work for the common good.

In methodological terms, we have operationalized the concept of social capital in three indicators that represent the standards indicators of associations (Bellucci, 2001):

- the membership rate, which measures the quota of people enrol at least to one association;

- the density rate, which measures multi-membership;

- the working membership, which is the percentage of people that take part actively in associative life.

As expected, membership in voluntary associations varies quite considerably across countries, but a file rouge cuts transversally across all the countries: the affiliation to Union and Party.

The overall average for membership is equal to $37,2 \%$ of the citizens that in these countries being a member of at least one association. The high is $69,9 \%$ in Slovenia, and the low is $10,8 \%$ in Poland.

In general, excluding Slovenia, the map of affiliation in associations draws that although positive experiences to resist communist authority don't feed an interest for apolitical associations. While the Union continues to play a key role in representing social interests and mediating between the civil and the political, the low 
levels of party association do register significance distrust and a sense of fed up with politics and politicians, as the case of Poland shows (Ekiert, Kubrik, 1999).

Tab. 2 Membership rate (\% values)

Source: Our analysis on the dataset of ICPR 2790

\begin{tabular}{|l|c|c|c|c|c|c|c|c|c|c|c|}
\hline & $\begin{array}{c}\text { No } \\
\text { member }\end{array}$ & $\begin{array}{c}\text { Churc } \\
h\end{array}$ & Sport & Arts & Unions & Party & $\begin{array}{c}\text { Envi- } \\
\text { rom. }\end{array}$ & $\begin{array}{c}\text { Pro- } \\
\text { fes. }\end{array}$ & $\begin{array}{c}\text { Char- } \\
\text { ity }\end{array}$ & Others & $\begin{array}{c}\text { Total } \\
(N)\end{array}$ \\
\hline Bulgaria & 74,9 & 2,5 & 2,1 & 1,4 & 10,4 & 3,9 & 0,4 & 1,9 & 1,2 & 1,4 & $\begin{array}{c}100,0 \\
(1.072)\end{array}$ \\
\hline Estonia & 57,3 & 7,8 & 6,5 & 7,1 & 10,4 & 1,0 & 1,4 & 4,3 & 1,9 & 2,4 & $\begin{array}{c}100,0 \\
(1.021)\end{array}$ \\
\hline Latvia & 54,3 & 7,6 & 4,6 & 4,5 & 11,7 & 1,9 & 1,2 & 8,3 & 1,9 & $4,2 \%$ & $\begin{array}{c}100,0 \\
(1.200)\end{array}$ \\
\hline $\begin{array}{l}\text { Lithua- } \\
\text { nia }\end{array}$ & 68,7 & 9,2 & 3,6 & 4,4 & 5,5 & 2,2 & 1,3 & 2,4 & 1,6 & 1,2 & $\begin{array}{c}100,0 \\
(927)\end{array}$ \\
\hline Poland & 89,2 & 0,0 & 0,0 & 0,0 & 9,6 & 1,1 & 0,0 & 0,0 & 0,0 & 0,0 & $\begin{array}{c}100,0 \\
(1.153)\end{array}$ \\
\hline Slovenia & 30,1 & 10,8 & 7,2 & 3,4 & 17,8 & 2,3 & 1,2 & 7,1 & 7,3 & 12,8 & $\begin{array}{c}100,0 \\
(1.007)\end{array}$ \\
\hline
\end{tabular}

Tab. 3 Multimembership rate (\% values)

\begin{tabular}{|l|c|c|c|c|c|}
\hline & 1 & 2 & 3 & 4 and more & $\operatorname{Total}(N)$ \\
\hline Bulgaria & 77,7 & 12,6 & 5,2 & 4,5 & $100,0(269)$ \\
\hline Estonia & 67,7 & 22,2 & 6,9 & 3,2 & $100,0(436)$ \\
\hline Latvia & 63,8 & 23,7 & 8,7 & 3,8 & $100,0(549)$ \\
\hline Lithuania & 73,8 & 17,2 & 4,9 & 4,1 & $100,0(325)$ \\
\hline Poland & 96,8 & 3,2 &, 0 &, 0 & $100,0(124)$ \\
\hline Slovenia & 50,7 & 28,8 & 12,4 & 8,1 & $100,0(704)$ \\
\hline
\end{tabular}

Source: Our analysis on the dataset of ICPR 2790

Tab. 4 Average Multimembership rate

\begin{tabular}{|l|c|c|c|}
\hline & Mean & Standard Deviation & $N$ \\
\hline Bulgaria & 1,3643 &, 77819 & 269 \\
\hline Estonia & 1,4564 &, 76138 & 436 \\
\hline Latvia & 1,5264 &, 80924 & 549 \\
\hline Lithuania & 1,3908 &, 76047 & 325 \\
\hline Poland & 1,0323 &, 17740 & 124 \\
\hline Slovenia & 1,7784 &, 95222 & 704 \\
\hline
\end{tabular}

Source: Our analysis on the dataset of ICPR 2790

We think this lack of affiliation to association is more structural than individual and is strongly related to the level of democracy (Paxton, 2002): if the political system doesn't allow them the possibility to exist, it is very difficult to expect a high number of associations, and consequently, of members. Nevertheless, if we exclude the Unions and Parties from analysis and focus our attention on non-political voluntary associations, the Church $(6,1 \%)$ is the voluntary association of greatest appeal, which shows that the work of the churches in the countries analyzed continues to bear weight in the process of democratization. 
From the prospective of social capital theory, to be a member of an association is undoubtedly less relevant than the existence of an associative network where the people are inserted. In fact it is important to stay in associative networks, to make possible that the norms of social capital self-generate (trust and reciprocity; Newton, 1998:169-187). Yet, multimembership also encourages the muting of extreme views favouring various relationships between civil society and democracy (Rueschemeyer, et al., 1998).

The analysis of variance ${ }^{1}$ shows that in the countries analyzed there are significance differentiations in terms of multimembership: country where the multimembership is more consistent is Slovenia where the $8,1 \%$ of people that are members of association attend four ormore associations (tab. 3), while the Poland, as showed before, remain the country where, probably, the political system have even a weight on the effective lift off of voluntary associations. The data doesn't explain the dynamics and the criteria by which the people choose associations, but considering the relationship between membership and multimembership, we can say that more membership equals more multi-membership, especially when the first one registers at a high level (fig. 1).

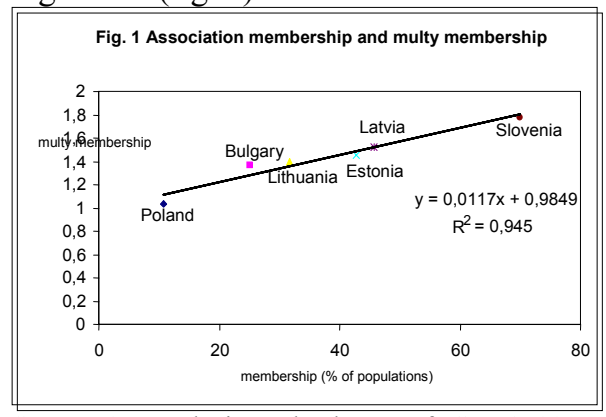

Source: Our analysis on the dataset of ICPR 2790 A necessary condition for development of social capital is interaction between the members. In fact, if participation is lim-

${ }^{1}$ The $\mathrm{F}$ is 19,520 , while df's are 5 ited to just the inscription, in formal terms, then both the activities of the association and the results of inscription itself - communication, socializations and so on - are weak.

The most associative activism is registered in Latvia $(9,9 \%)$ and Estonia $(9,3 \%)$, while Poland has the lowest percentage of associative activism (tab. 5).

Tab. 5 Working membership (\% values)

\begin{tabular}{|l|c|c|c|c|}
\hline & $\begin{array}{c}\text { No mem- } \\
\text { ber }\end{array}$ & Passive & Active & Total $(N)$ \\
\hline Bulgaria & 74,9 & 16,9 & 8,2 & $\begin{array}{c}100,0 \\
(1.072)\end{array}$ \\
\hline Estonia & 57,3 & 33,4 & 9,3 & $\begin{array}{c}100,0 \\
(1.021)\end{array}$ \\
\hline Latvia & 54,3 & 35,8 & 9,9 & $\begin{array}{c}100,0 \\
(1.200)\end{array}$ \\
\hline $\begin{array}{l}\text { Lithua- } \\
\text { nia }\end{array}$ & 67,8 & 23,9 & 8,3 & $\begin{array}{c}100,0 \\
(1.009)\end{array}$ \\
\hline Poland & 89,2 & 8,3 & 2,5 & $\begin{array}{c}100,0 \\
(1.153)\end{array}$ \\
\hline Slovenia & 30,1 & 54,6 & 15,3 & $\begin{array}{c}100,0 \\
(1.153)\end{array}$ \\
\hline
\end{tabular}

Source: Our analysis on the dataset of ICPR 2790

The values for activism are relative to the total number of members. To understand where activism is more evident we need to compute another measure: the ratio between active and passive members.

In fact, considering this ratio it is possible to understand that even where we can found high levels of membership or multimembership, there is not always significance activism inside the association. An exemplificative case is Slovenia, where the ratio of active to passive members is 0,28 , while Lithuania, the country where the associative life is more active, has a ratio of 0,35 (tab. 6).

Tab. 6 Working membership rate (odds

\begin{tabular}{|l|l|}
\hline Bulgaria & 0,05 \\
\hline Estonia & 0,28 \\
\hline Latvia & 0,28 \\
\hline Lithuania & 0,35 \\
\hline Poland & 0,30 \\
\hline Slovenia & 0,28 \\
\hline
\end{tabular}
ratio)

Source: Our analysis on the dataset of ICPR 2790 
Considering this first analysis we can confirm the heavy weight that the dictatorship has had on social capital, but in the same time we can say that the results are comfortable especially if we consider: on one hand, the period of the study (1995-1997), and on the other hand, that these countries have reached democracy in the 1990s. This is not just a hope, but a certainly, because the results that Barnes reports in a study on the same Eastern countries, comparing two specific wave of research (1990-1992 and 1998-2001), shows that the level of social capital is low just for structural and not individual factors. Considering all the indicators, which is the country where social capital is greatest? To answer this question we have explored the relationship among the indicators of social capital using a factor analysis (tab. 7). The factor analysis was done twice because the first time (Tab. 7) the concept of trust and the indicators of associative life didn't have a relationship in the Eastern countries. For this reason, we will consider them in a differentiated way, because we cannot forget that trust is a good lubricant for corporate efficiency

The second factor analysis' results confirmed the power explicative of this analysis in terms of variance $(85,7 \%)$ and its high validity and reliability with an Alpha of Cronbach of,8542.

Tab. 7 Factor and reliability analysis of social capital

\begin{tabular}{|l|c|c|}
\hline & $\begin{array}{c}\text { Fist } \\
\text { analysis }\end{array}$ & $\begin{array}{c}\text { Second } \\
\text { analysis }\end{array}$ \\
\hline Trust &, 062 &, 869 \\
\hline Membership &, 867 &, 970 \\
\hline $\begin{array}{l}\text { Multimember- } \\
\text { ship }\end{array}$ &, 970 &, 935 \\
\hline $\begin{array}{l}\text { Working asso- } \\
\text { ciation }\end{array}$ &, 934 & 85,7 \\
\hline $\begin{array}{l}\text { \% variance } \\
\text { Alpha of } \\
\text { Cronbach }\end{array}$ & 64,2 &, 8542 \\
\hline
\end{tabular}

Extraction method: Principal Component analysis transformed with varimax rotations
Source: Our analysis on the dataset of ICPR 2790 Considering the three indicators as a cumulative index we can see that among the countries considered, Slovenia is the country that has the most social capital $(2,845)$, while Poland $(, 350)$ has the least. Although the range is very large, we cannot reject the null hypothesis that the countries have different variances (Leven Test, sig. ,000). So there are differences among the countries in terms of social capital (Anova, sig. ,000; tab. 8). But, some measures appear very close to solicited to go deep in this relationship.

Tab. 8 Social capital Index (\% values)

\begin{tabular}{|l|c|c|c|}
\hline & Mean & $\begin{array}{c}\text { Standard } \\
\text { deviation }\end{array}$ & $N$ \\
\hline & & & \\
\hline Bulgaria &, 938 & 1,70788 & 1.072 \\
\hline Estonia & 1,583 & 1,94237 & 1.021 \\
\hline Latvia & 1,716 & 1,96298 & 1.200 \\
\hline Lithuania & 1,162 & 1,84956 & 927 \\
\hline Poland &, 350 & 1,02166 & 1.153 \\
\hline Slovenia & 2,845 & 2,11448 & 1.007 \\
\hline Total & 1,415 & 1,95043 & 6.380 \\
\hline
\end{tabular}

Source: Our analysis on the dataset of ICPR 2790

After this analysis, one first conclusion is the following:

- the level of trust in others in the Eastern countries is low;

- membership varies across the countries, although the range of variation has not been emphasized too much. Besides, two specific associations (unions and parties) are a peculiarity of the countries analyzed. In these terms, if we don't consider these two typologies of associations in our analysis, the differences in membership rate decrease considerably;

- it's not possible to draw a pattern of multi-membership, but we can say there is a strong linear relationship 
between membership and multimembership;

- working membership appears far from a specific pattern of voluntary associations;

- social capital in Eastern countries is created more by associative behaviour than trust in others.

Democracy and Confidence in institutions The gap in social capital between Eastern and Western Europe can be largely attributed to economic and institutional differences (Fidrmuc, Gerxhani, 2004). Putnam's (1993) and Fukuyama (1995) analyses of formal institutions have often been mentioned as important causes of different levels of social capital in developed countries or within a developed country itself (Fukuyama, 1995, Putnam et al., 1993). While, the concept of confidence in institutions seems to be very important if we consider that citizens in transition countries seem to have much higher esteem for their institutions (Rose, Mishler and Haerpfer, 1998).

Nevertheless, distrust in public institutions is thus one of the most pernicious legacies of Communism (Gati, 1996). Like Stiglitz (1996) describe, there are ways for governments to build trust in public institutions by offering dialogue and consulting power to members of the public over important policy changes.

From a methodological view, the institutions that give a major explanation about the confidence aren't apparent.

In fact:

i) some authors considered just the public institutions, for example the parliament, the parties, the civil services, and so on (Orren, 1997, Dalton, 1999);

ii)others scholars used both the public and private institutions (for example: mass media, trade unions, church, and so on; Lipset \& Schneider, 1983).
In this sense, confidence in institutions is measured considering attitudes towards the political system (system effect) that ensure the legitimacy of democracy (Almond \& Verba, 1963), since, one of the goals of a new regime is to establish institutions that are acceptable, in terms of confidence, by comparing themselves with previous regimes (Rose, 1992). In a post-Communist country, most institutions of past regimes remain in place, so to compare institutions is determinant to understand how and how much confidence people have in the institutions representative of democracy (Welsh, 1996).

Beside confidence in institutions represents a good measure of democratic support: if the institutions represent the citizens, the people will have confidence in them only if they are deemed trustworthy. In this sense, as many scholars recognize, it's important to consider the democracy support in the analysis of democracy (Korberg, Clark, 1992).

Considering seven specific public institutions, that the institution in which people have more confidence is the armed forces, while regard the party and parliament, which in the collective imagination represented the past, the confidence level register a percentages equal to 17,1 and 33,2 (tab. 9).

Tab. 9: Confidence in institutions (great + quite)

\begin{tabular}{|l|c|}
\hline & Values $\%$ \\
\hline Armed Force & 54,3 \\
\hline Legal System & 41,7 \\
\hline Police & 41,7 \\
\hline National Government & 43,9 \\
\hline Party & 17,1 \\
\hline Parliament & 33,2 \\
\hline Civil Service & 43,1 \\
\hline
\end{tabular}

Source: Our analysis on the dataset of ICPR 2790

Other studies consulted present the same scenario: these values don't evidence anti- 
political or anti-government attitudes, but just scepticism towards institutions that represent democracy (Rose, et al., 1998).

Bulgaria is the country with the most confidence in the armed force $(81,4 \%)$, followed by Poland (79,5\%, tab. 10).

In Estonia the legal system receives the most confidence $(61,7 \%)$, while in Latvia and Lithuania it is the civil service $(44,1 \% ; 41,0 \%)$. Particularly interesting is the case of Slovenia, where the confidence level is highest for police.

So, it is possible to understand the scenery in the countries analyzed is not very heterogeneity in terms of confidence. But the most interesting aspect is the fact that in any country the national government, the party or the parliament are the institutions in which there is the citizens' greatest confidence. If we think that these three institutions represent, in Western Europe, the concept of democracy, it's easy to deduce that in the countries analyzed the scepticism could be a problem for the process of democratization. In fact considering the study of Rose et al. (1998:154), which considers some countries analyzed in this study (Slovenia, Poland and Bulgaria), the parliament, the national government and the parties are the first three public institutions that registered the highest values of distrust.

Tab. 10: Confidence in public institutions by country (great + quite)

\begin{tabular}{|l|c|c|c|c|c|c|c|}
\hline & Armed force & $\begin{array}{c}\text { Legal } \\
\text { system }\end{array}$ & Police & $\begin{array}{c}\text { National } \\
\text { Government }\end{array}$ & Party & Parliament & $\begin{array}{c}\text { Civil } \\
\text { Service }\end{array}$ \\
\hline Bulgaria & 81,4 & 38,6 & 51,2 & 59,9 & 29,2 & 45,3 & 48,0 \\
\hline Estonia & 47,9 & 61,7 & 50,9 & 50,2 & 23,2 & 43,8 & 60,9 \\
\hline Latvia & 30,9 & 38,3 & 31,1 & 38,3 & 10,3 & 25,0 & 44,1 \\
\hline $\begin{array}{l}\text { Lithua- } \\
\text { nia }\end{array}$ & 40,8 & 22,2 & 20,8 & 36,3 & 14,4 & 26,5 & 41,0 \\
\hline Poland & 79,5 & 52,6 & 53,2 & 39,0 & 12,8 & 34,5 & 35,1 \\
\hline Slovenia & 44,7 & 35,9 & 47,4 & 40,6 & 13,7 & 24,7 & 28,9 \\
\hline
\end{tabular}

Source: Our analysis on the dataset of ICPR 2790

The confidence in institutions is also a good indicator of democracy support.

In fact cultural approaches measures support indirectly based in the assumption that democracy requires a civic culture in which citizens manifest such basic values as trust. The assumption is that societies with low levels of trust are poorly suited to the establishment of democratic institutions (Putnam, 1993).

To obtain a measure of democracy support we transform the confidence in each public institution in an index using the factor analysis (Tab. 11), and controlling the scale obtained by reliability analysis. The factor analysis presents acceptable results (chi-square $=829,790 ; \mathrm{df}=14$ ), and the reliability of the scale is good (Alpha= ,8280).

Tab. 11: Factor and reliability analysis of democracy support

\begin{tabular}{|l|l|}
\hline Armed Force &, 566 \\
\hline Legal System &, 652 \\
\hline Police &, 689 \\
\hline National Government &, 805 \\
\hline
\end{tabular}




\begin{tabular}{|l|l|}
\hline Party &, 700 \\
\hline Parliament &, 814 \\
\hline Civil Service &, 697 \\
\hline \% variance & 50,1 \\
\hline Alpha of Cronbach &, 8280 \\
\hline
\end{tabular}

Extraction method: Principal Component analysis transformed with varimax rotations.

Source: Our analysis on the dataset of ICPR 2790

Confidence in institutions, obviously, demonstrates a good level of trust by the citizens represented: if there is trust on a generalized level probably there is confidence in institutions, although the reverse doesn't work well.

In fact, measuring this relationship with a polynomial regression model (fig. 2), the trust in others appears to be the predictor criteria useful to formulate a judgment on the public institutions, and, consequently, the base element to increase the level of democratization. Democratic societies are trusting societies. Societies have higher levels of trust in turn have institutions that function better. As Rothstein (2001) says: "If people believe that the institutions that are responsible for handling 'treacherous' behaviour act in fair, just and effective manners, and if they also believe that other people think the same of these institutions, then they will also trust other people."

In this sense if we withheld trust in people until we had confidence that they were in fact trustworthy, then government might be able to generate faith in others because confidence in government is contingent upon our evaluations of how well our leaders have done their jobs (Fenno, 1978; Bianco; 1994).

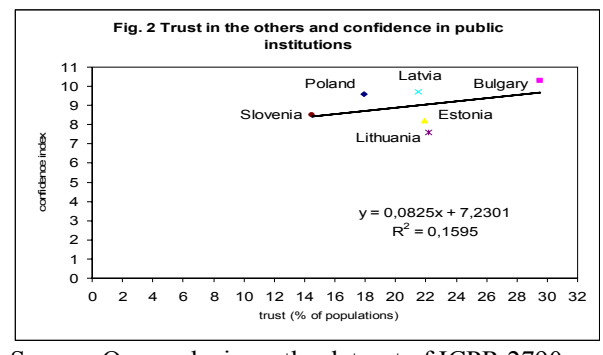

Source: Our analysis on the dataset of ICPR 2790

Democratization, social capital and confidence in institutions: an explicative model

The measure of democratization level across the countries considered in this work is that of Freedom House (1997), which represents a synthesis of cultural differences, diverse national interests, and varying levels of economic development (laws, political, and economic factors and actual violations, or repressive actions). The rating is structured on a continuum that represents the hierarchical list of the countries, from the first, which have lower scores and represent the highest level of democracy, to the last with high scores and the lowest level of democracy. In this analysis we apply a structural equation model, reading the standardize values, that consent to understand the weight of each variables on the democracy level as well as the importance of the same aspects. We consider the variables as indicated and we analyze some sociodemographic aspects (age and education), in order to give an answer to some questions that were generated during the redaction of this paper.

The first one is: what is the relationship between trust and democracy?

Many authors support the idea that governments produce democracy (Choen, 1997, Levi, 1998, 1999; Offe, 1999) assuming that democracy is explicative of the trust.

We disagree with this causal relationship because the democracy cannot produce trust, but vice versa. Trust can produce confidence in the governments. Inghleart 
(1999) and Uslaner (2002) say that democracy and trust go together, but there is a little evidence that democratization leads to greater trust.

Our analysis confirms this tendency (fig. 3 ): the more people trust in others, the greater the increase in the level of democratization $(\mathrm{B}=, 15)$. But when we consider the inverse relationship, the value is negative $(B=-, 21)$ : evidence that, on one side, democratization doesn't produce trust, and on the other side, there is not a conceptual base to support the idea that increasing the democratization decreases trust in others. Others studies on the same countries come to the same conclusion in terms of a direct relationship (Barnes, 2004).

In other words, like Uslaner (1999), we admit the superiority of social trust over participatory behaviour arguing that "civic networks may enhance social life, but this "social connectedness" ... is distinct from - and secondary to - moral values" (Uslaner 1999: 122).

The trust contributes to explaining social capital and confidence in institutions too.

Regarding confidence in institutions, the low value of beta $(, 01)$ is explicative of low or scarce trust of people towards politicians. As Earle (1995) said, while the social trust is based in the here and now, confidence in institutions is based on past experience. In this sense, the low but positive contribution, in explicative terms, of the trust in others on confidence in institutions, which is an indirect indicator of democracy support, is evident that citizens are begging to remove the shadow of the past regime (communism) in fiduciary terms.

As explained in the preceding pages, the trust doesn't have a strong connection with social capital. In fact, the results of factorial analysis suggest keeping it out from the social capital index (Tab. 8). This doesn't indicate that trust has no relationship with social capital, but just that in the Eastern countries the composition of social capital assumes a different form. Nevertheless, trust contributes to create social capital (beta $=, 04$ ).

Regarding the social capital as an extension of associative life, some authors give evidence that it appears oriented towards the loyalties and resources of their membership (Howard, 2003) and also creates a living environment independent of the public sphere (Geremek 1992). Social capital has a good relationship both with the democratic support (confidence in institutions) and with the democratic level.

As Verba and Nye say, organizations increase "the potency of the citizenry vis-àvis the government in a number of ways. Organizations through their paid officials speak for their members.... or an individual can gain access to the government through the organization, or organizations may have an impact on political life in a society through the influence they have on the participatory activities of their members. Citizens may participate directly because of their affiliation with an organization.... A rich political participant life may rest on a rich associational life" (1972:175).

Citizens with a high level of education see in the social capital a good medium (beta $=, 05)$ to participate in the social and political life. Along with education (beta $=, 15$ ) having employment is linked with the democratic level. (beta=,04). In this sense, cultural opening (high level of education) and economic stability (occupation) are two good hinge elements to increase the democratic level.

The third aspect is the confidence in public institutions. This indicator, constructed using just public institutions, as we said before, is an indirect indicator of democracy support. In this sense it measures the (specific) support for democracy through the confidence in institutions.

From this analysis a negative relationship emerges between democracy support and democratic level. 
In analysis on the Western countries in the last years few years, popular confidence for political institutions appears to be declining (Pharr et al., 2000). The same situation is registered in the Eastern countries where the relationship between democracy support and level of democracy is negative (beta $=0,8$ ) evidencing that democracy support and level of democracy don't go hand in hand.

If we consider on one hand, that the distrust for politicians or parties is a peculiarity of many eastern countries (Schmitter, 1994) as our data confirm especially towards the party and parliament, and on the other hand, that diffuse support (legitimization) and specific support (in this case the confidence in institutions) represent the viability of a political system (Easton, 1975), we can understand that slow reform may cause disillusionment in the citizenry, and often slows the democracy consolidate process (Waldrom More, 1999).

Regarding two socio-economic variables, education and professional condition, a high level of education and job stability are good predictors of democracy support, as other analysis confirms (Waldrom More, 1999), as well as democratic level. Conclusions

In this paper we've considered the relationship between democratic level and three specific aspects: trust, social capital and democracy support.

Trust has a direct effect on the democratic level but not the contrary, confuting the position of many authors, like Levi, and others. In fact the direct and indirect effects, in measurement terms, in our model, show the fallacy of the idea that democracy can construct trust among citizens.

The social capital, although it has had many critics especially when considered in relation to West countries, presents an appreciable explicative power both in terms of confidence in institutions and democratic level. This result confirms its importance in the process of democratization, and at the same time disconfirms the Dowley and Silver's (2001) analysis, that showed a failure to find relation between measures of social capital and democratization in eastern countries. The use of just "membership rate" as an indicator of social capital, as in Dowley and Silver (2001), is not sufficiently reliable. In this sense, complex measures, as is social capital, constructed on just indicators give misleading results.

The negative relationship between confidence in institutions and democratic level shows the imbalance between expectations of the citizens and outcomes received. It's clearly demonstrated by the low level of trust that the people have in institutions, especially party, parliament and legal system. Thus, it is the task of public institutions to work hard to create consensus among the citizens. 
Fig. 3 Democratization in Eastern Countries

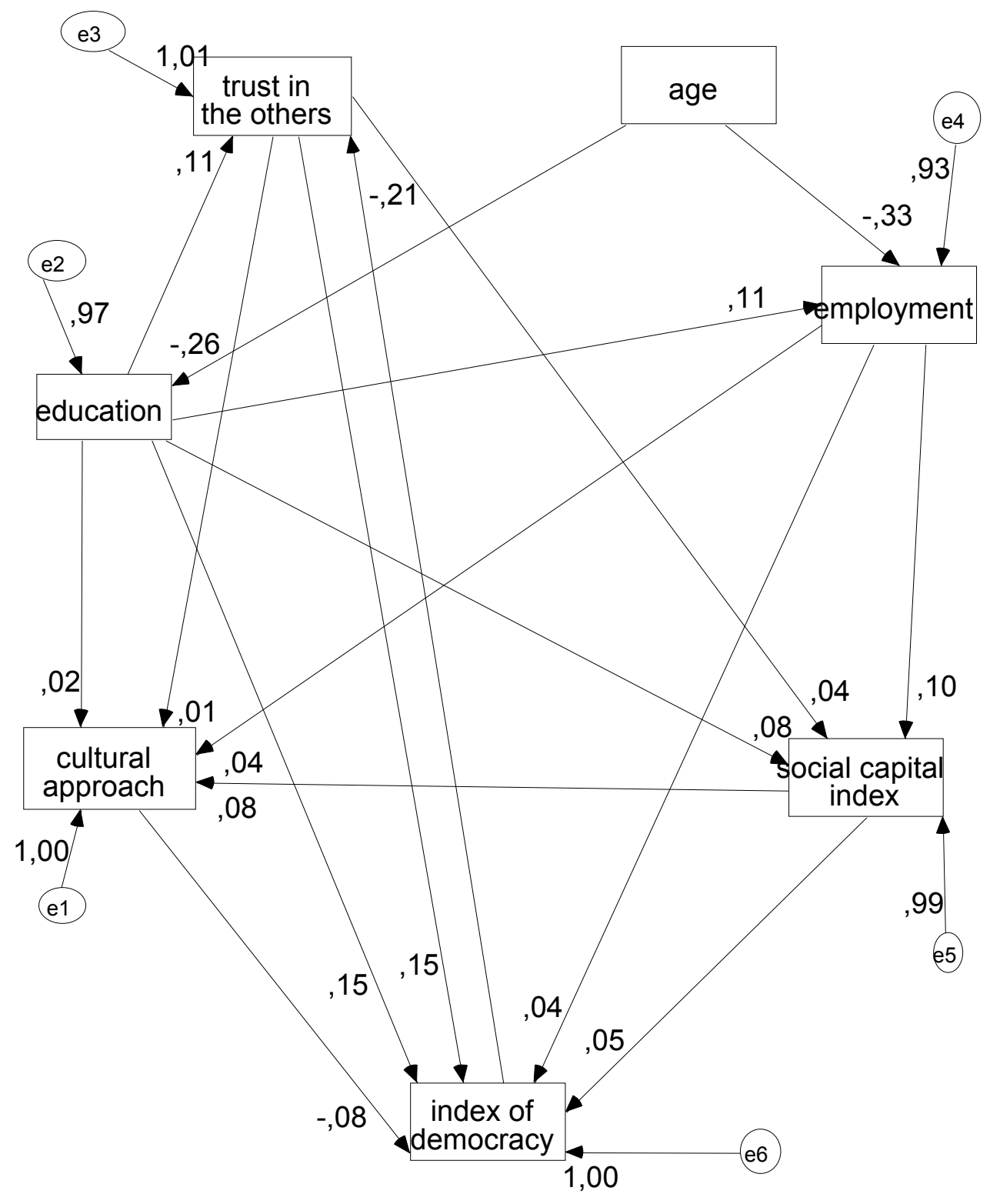

Standardized estimates

chi-square $=2,808 \mathrm{df}=4 \mathrm{p}$-value $=, 590$

gfi $=1,000$ agfi $=, 999$ rmsea $=, 000$

nfi $=, 998$ ifi $=1,001$ pclose $=1,000$ 
Appendix - Description of Variables used in structural equation model ${ }^{1}$

Trust in the others (v27)

Questioning wording: Generally speaking, would you say that most people can be trusted or that you can't be too careful in dealing with people?

The modality of response, after recoded was the following: 0 Can't be too careful - 1 Most people can be trusted

Age (v216)

Questioning wording: This means you are years old.

Education (v217)

Questioning wording: What is the highest educational level that you have attained?

Employment (v220)

Questioning wording: Are you employed now or not? *IF YES: About how many hours a week? If more than one job: only for the main job. The modality of response, after recoded, was the following: 0 Not employed 1 Employed

Cultural approach (v136 v137 v141 v142 v143 v144 v145)

Questioning wording: I am going to name a number of organizations. For each one, could you tell me how much confidence you have in them: is it a great deal of confidence, quite a lot of confidence, not very much confidence or none at all? The modality of response, after recoded was the following: 4 a great deal of confidence, 3 quite a lot of confidence, 2 not very much 1 confidence or none at all

Social capital index (v28 v29 v30 v31 v32 v33 v34 v35 v36)

Question wording: Now I am going to read off a list of voluntary organizations; for each one, could you tell me whether you are an active member, an inactive member or not a member of that type of organization?

Index of democracy

The rating of Freedom House (1997) is used and recoded in mode that at the maxim level it expresses the highest level of democracy.

\section{References}

Almond, G. and Verba, S. (1963). The Civic Culture. Princeton, NJ: Princeton University Press

Arrow, K. (1972) 'Gifts and exchanges', Philosophy and Public Affairs, 1 (Summer) Barnes, S., (2004), Political Participation in Post-Communist Central and Eastern Europe, press Center for the Study of Democracy, paper 4-10

\footnotetext{
${ }^{1}$ In the analysis we don't have considered the missing values
} 
Bellucci, P., Maraffi M., Segatti P., (2001), Politicized secondary associations. Political partecipation, social capital and democracy (paper presented to CNEP meeting September, Santiago del Cile)

Bielasiak, J., (2002), The Institutionalisation of Electoral and Party Systems in Postcommunists States, in Comparative Politics, 34:189-210

Bourdieu, P. (1983): "The Forms of Capital", in Richardson, J., (1986), Handbookof Theory and Research for the Sociology of Education, (eds), 241-258, New York: Greenwood Press

Bunce, V. J., (1984), The Empire Strikes Back: The Evolution of the Eastern Bloc from a Soviet Asset to a Soviet Liability, in International Organization, 39: 1-46

Cohen, J. L., (1997), American Civil Society Talk, College Park, MD: National Commission on Civic Renewal, Working Paper 6

Cohen, D., Prusak, L., (2001), In Good Company. How social capital makes organizations work, Boston, Ma.: Harvard Business School Press

Coleman, J.S. (1988): "Social Capital in the Creation of Human, in Journal of Sociology, 94: s95-s120, Special Supplement

Dalton, R. J., (1999), Political Support in Advanced Industrial Countries, in Norris P., (ed.), Critical Citizen: Global Support for Democratic Government, Oxford: Oxford University Press

Di Palma, G.,1990, To craft democracies: an essay on democratic transition, Berkley, CA: University of California Press

Diamond, L., (1997), Consolidating Democracy in the Americas, in Annals of The American Academy of Political and Social Science, 550:12-41

Dowley, K. M., Silver, B. D., (2001), Social Capital, Ethnicity, and Support for Democracy in the Post-Communist States, paper presented in meeting of the Midwest Political Science Association, April 18-22

Earle, T. C., Cvetkovich, G. C., (1995), Social Trust: Towards A Cosmopolitan Society, Praeger, Westport

Earle,T.C., Social Trust and Confidence, in http://www.trustnetgovemance.com/library/pdf/doc8.PDF

Easton, D., (1965), A systems analysis of political life, New York: John Wiley

, (1975), A re-assessment of the concept of political support, in British Journal of Political Science, 5:435-457

Eckstein , H., (1988), A culturalist theory of political change, in American Political Science Review, 82:789-804 Freedom House, (1995-1999) 
Ekiert, G, Kubik, J., (1999), Rebellious Civil Society: Popular Protest and Democratic Consolidation in Poland, 1989-1993, Ann Arbor: University of Michigan Press

Elster, J., (1999), Il cemento della società, Bologna:IlMulino

Fountain, J. E. (1998). Social capital: Its relationship to innovation in science and technology. Science \& Public Policy, 25, 2:103-107

Fung, A., (2003), Designing Democracy, Princeton: Princeton University Press

Fukuyama, F., (1995), Trust: The Social Virtues and the Creation of Prosperity, London: Hamish Hamilton

, (1999, November). Social capital and civil society. Paper presented at the Conference on Second Generation Reforms IMF Headquarters, Washington, D.C.

Gati, C., (1996), The mirage of democracy, in Transition, 22:6-12

Geremek, B., (1992), Civil Society Then and Now, in Journal of Democracy, 3:3-12

Huntington, S.P., (1990), The Third Wave. Democratization in the Late TwentiethCentury, Oklahoma: University of Oklahoma,

Inglehart, R., ICPSR, World Values Survey and European Values Survey, 19951997, 2710, Ann Arbor: Inter-University Consortium for Political and Social Research

Princeton University Press

(1990), Culture shift in advanced industrialized society, New York: (1997), Modernization and Postmodernization: Cultural, Economic, and Political Change in 43 Societies, Princeton: Princeton University Press

, (1999), Trust, Well-Being and Democracy, in Warren, M., (eds.), Democracy and Trust, Cambridge: Cambridge University Press

, (1997), Modernization and Postmodernization: Cultural, Economic, and Political Change in 43 Societies, Princeton: Princeton University Press Books

Jacobs, J., (1961), The Death and Life of Great American Cities, New York: Vintage

Jedlowski P., (1995), Gorge Simmel. Le metropoli e la vita dello spirito, (eds), Roma: Armando

Kavanagh, D., (1980), Political Culture in Great Britain: The Decline of the Civic Culture in Almond, G.A., and Verba, S., (eds.), The Civic Culture Revisited, Boston: Little Brown and Company, pp. 124-76 
Korberg, A., Clarke, H. D., (1992), Citizens and Community: Political Support in Representative Democracy, Cambridge and New York: Cambridge University Press

Kornhauser, W., (1960), The Politic of Mass Society, London: Routledge \& Kegan Paul

Levi, M., (1998), A State of Trust, in Levi, M., Braithwaite, V., (eds.), Trust and Governance, New York: Russell Sage Foundation

(1999), When Good Defenses Make Good Neighbors: A Transaction Cost Approach to Trust and Distrust, New York: Russell Sage Foundation Working Paper 140

Linz, J. J., (1988), Legitimacy of Democracy and Socioeconomic System, in Dogan, M., (eds.), Comparing Pluralist Democracies, Boudler: Westview Press

Linz, J.J. and A. Stephan, (1996), Problems of Democratic Transition and Consolidation. Southern Europe. South America, and Post-Communist Europe, Baltimore, The Johns Hopkins University Press

Lipset, S. M., (1960), Political Man, New York:Vintage Book

Lipset, S. M., and W., Scheneider, (1983), The confidance gap: Business, labor, and government in the public mind, New York: Free Press

Lipset, S. M., (1994), The Social Requisites of Democracy Rivisited. 1993 Presidential Addres, in American Sociological Review, 59, 2:1-22

Lundestad, G. (1998), Empire By Integration - The United States and European Integration, 1945-1997, Oxford: Oxford University Press

Mainwairing S., O’Donnell, G., Valenzuela, J. S., 1992, Issue in democratic consolidation: The new South America democracies in comparative perspective, Notre Dame, IN: University of Notre Dame Press

Morlino, L., (1998), Democracy Between Consolidation and Crisis: Parties, Groups, and Citizens in Southern Europe, New York: Oxford University Press

Newton, K., 1998, Social and Political Trust in Established Democracies, in Norris P., (1998), Critical Citizens. Global Support for Democratic Government, (eds.), Oxford: Oxford University Press

O’Donnel, G., Schmitter, P. C., 1986, Tentative conclusion about uncertain democracies, in Transition from authoritarian rule: Prospects for democracy, Baltimore, MD: John Hopkins University Press 
Offe, C., (1999), Trust and Knowledge, Rules and Decisions: Exploring a Difficult Conceptual Terrain, in Warren, M., (eds.), Democracy and Trust, Cambridge: Cambridge University Press

Orren, G., (1997), Fall from Grace: The Public's loss of Faith in Government, in Nye, J. S. Jr., Zelikow, P. D., King, D. C., (ed.), Why People Don't Trust Government, Cambridge, Mass: Harvard University Press

Ostrom, E., (1990), Governing the Commons: The Evolution of Institutions for Collective Action, New York: Cambridge University Press

Paldam, M., Svendsen, G.T., (2000), An essay on social capital: Looking for the fire behind the smoke, in European Journal of Political Economy 16: 339-366

Paxton P., (2002), Social capital and democracy: An interdependent relationship, in American Sociological Review, 67:254-77

Paldam, M., Svendsen, G. T., (2000), Missing Social Capital and the Transition in Eastern Europe, Papers 00-5, Aarhus School of Business - Department of Economics.

Przeworski,A., 1991, Democracy and the Market: Political and Economic Reforms in Eastern Europe and Latin America, New York: Cambridge University Press

Putnam, R., (1993), Making Democracy Work: Civic Traditions in Modern Italy, Princeton, NJ: Princeton University Press

nal of Democracy $, 6: 65-78$

(1995), Bowling Alone: America's Declining Social Capital, in Jour, (2000) Bowling alone: The collapse and revival of American community, New York: Simon Schuster

Raiser, M., 1999, Trust in transition, EBRD working paper, n. 39, London

Rose, R., (1992), Escape from Absolute Dissatisfaction: A Trial an Error Model of Change in Eastern Europe, in Journal of Theoretical Politics, 4, 4:371-93

Rose, R., Mischeler, W., Haerpfer, C., (1998), Democracy and Its Alternative. Understanding Post Communist Societies, Baltimore, Mariland: The John Hopkins University Press

Rueschemeyer, D., Rueschemeyer, M., Wittrock, B., (1998), Participation and Democracy East and West. Comparisons and Interpretations. Armonk, London: M.E. Sharpe

Rustow, D., (1970), Transition to Democracy, in Comparative Politics, 1:337-63 Serageldin I. (1996), Sustainability as Opportunity and the Problem of Social Capital, in The Brown Journal of World Affairs, 3:187-203 
Shin, D. C., (1994), On the Third Wave of Democratization. A Synthesis and Evaluation of Recent Theory and Research, in World Politics, 47:135-70, October

Simmel, G., (1950), The Sociology of George Simmel, NY: The Free Press

Starr, H., (1991), Democratic Dominoes: Diffusion Approaches to the Spread of Democracy in International System, in Journal of Conflict Revolution, 35, June

Schmitter, P. C., (1994), Interests, Associations and Intermediation in a Reformed Post-Liberal Society, in Wolfgang, S., (eds.), Staat und Verbände, Opladen: Westdeutscher Verlag, 160-171

Stiglitz J., (1996), Some lessons from the East Asian Miracle, the World bank research observer, vol. II, 2:151-77

Tocqueville, Alexis de, (1968), Democracy in America, London : Fontana

Uslaner, E. M., (2002), The moral foundation of trust, New York, Cambridge University Press

Verba, S., Normann, N., (1972), Participation in America, New York, Harpen \& Row

Waldrom More, P., (1999), Eastern Europe at The Crossroads of the democratic transition. Evaluating Support for Democratic Government, and Consolidation of Democratic regimes, in Comparative Political Studies, 32, 1:32-62

Warren, M.E., (1999), Democracy and Trust, (eds.), Cambridge: Cambridge University Press, (2001), Democracy and Association, Princeton: Princeton University Press

Weatherford, M. S., (1989), Political economy and political legitimacy: The link between economic policy and political trust, in Clarke, H., Stewart, M., Zuk, G., Economic decline and political change, (eds) Pittsburgh, PA: University of Pittsburgh Press

Welsh, H. A., (1996), Dealing with the Communism Past: Central and Eastern European Experience after 1990, in European-Asian Studies, 48, 3:413-28

Wildavsky, A., (1987), Choosing preferences by constructing institutions: Culture theory of preferences formation, in American Political Science Review, 81:3-12 